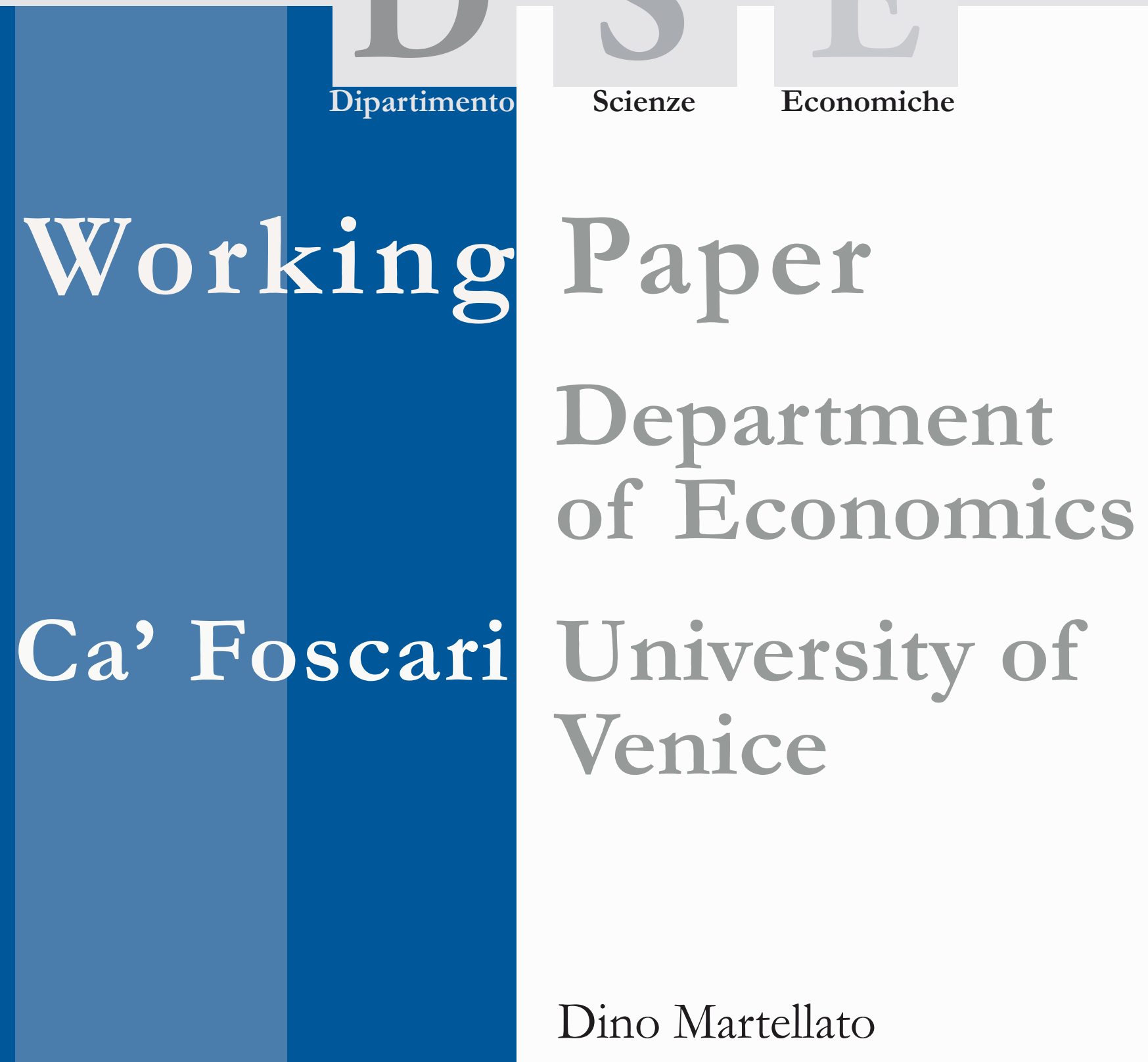

Economic Integration and Macroeconomic Convergence in the Euro Area 


\title{
Economic Integration and Macroeconomic Convergence in the Euro Area
}

\author{
Dino Martellato \\ Università Ca’ Foscari di Venezia
}

First Draft: April 2008

\begin{abstract}
In this paper I discuss various notions and aspects of integration and macroeconomic convergence, namely economic and monetary integration; real and nominal convergence. The EU has offered a great deal of information about the relation between all these types of integration and macroeconomic convergence. The EU has assumed that monetary integration is a precondition of deep economic integration and it has also assumed that the criteria to be adopted to converge to its own brand of economic and monetary union (EMU) are basically the same needed within the monetary union itself. Judging from the evidence of the first ten years of EMU, the actual relationship between real growth and inflation has turned out to be far from clear; and the paper provides a comparison between statistical evidence and the diverging predictions offered by two standard macroeconomic models.
\end{abstract}

\section{Keywords}

Inflation, stability, euro zone

\section{JEL Codes}

E12, E41, E52, E63

Address for correspondence:

Dino Martellato

Department of Economics Ca' Foscari University of Venice Cannaregio 873, Fondamenta S. Giobbe 30121 Venezia - Italy Phone (++39) 0412349157 Fax (++39) 0412349176 marteld@unive.it

This Working Paper is published under the auspices of the Department of Economics of the Ca' Foscari University of Venice. Opinions expressed herein are those of the authors and not those of the Department. The Working Paper series is designed to divulge preliminary or incomplete work, circulated to favour discussion and comments. Citation of this paper should consider its provisional character.

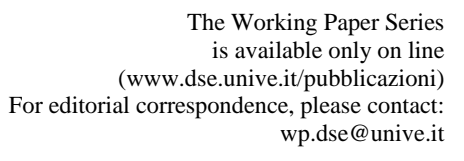

Department of Economics

Ca' Foscari University of Venice

Cannaregio 873, Fondamenta San Giobbe

30121 Venice Italy

Fax: ++39 0412349210 


\section{Introduction}

Integration is something that economists, historians and other social scientists have always liked to study, but which has always been up to political leaders to implement. The EU (European Union) and EMU (Economic and Monetary Union) are obvious cases in point as they in part reflect economic theory, but were put forward by leaders which only subsequently submitted them either to Parliament or to the people. No wonder that what Europe is doing is observed as a case study of unprecedented complexity and looked at with a mixture of sentiments which include interest, scepticism, hope and disillusion. In this paper we focus on EMU, which lies at the core of the experiment and in particular on the connections between the economic paradigm regarding integration and macroeconomic convergence and the actual economic policy-making which occurs in the Euro area. First of all, we highlight differences between economic integration and monetary integration. We then move to macroeconomic convergence. First, we look at the criteria adopted in the assessment of whether a country is converging or not before and after adoption of the common currency . We then make a distinction between real convergence and nominal convergence and their mutual relationship. The subsequent section is devoted to the assessment of the relationship between inflation and real growth on empirical and theoretical grounds.

\section{Economic Integration vs Monetary Integration}

Although there are deeply connected aspects between economic integration, exchange rate regimes and monetary integration, it is worth keeping them separated when discussing actual unions such as customs unions (European Economic Community, European Free Trade Agreement), currency unions (East Africa Currency Area, Belgium-Luxembourg, European Monetary System) and monetary unions (EMU) which have different dosages of integration in real and monetary matters. 
As far as economic integration is concerned, factor mobility is the most-cited single criterion for adopting a fixed exchange rate regime. The theory of optimal currency areas was a purely academic exercise started by Mundell (1961) and based on the idea that regions with strong mobility of production factors do not need exchange rate flexibility. It is a pity, however, that regions do not have distinct currencies and over time the pattern of mobility of factors can change considerably. The concept of optimal currency is clearly useless in understanding EMU. Trade openness is a different criterion from factor mobility, although it has similar implications for the exchange rate regime (McKinnon, 1963). Small economies are very open, thus exchange rate fluctuations have a large impact on internal prices. The lower insulation that flexible exchange rates deliver in small and open economies means that there is nothing to be gained by floating the local currency against the currencies of their major trading partners.

A third concept is path-dependence. Various authors have claimed that the historical degree of openness and factor mobility may not be necessary conditions for a successful currency union. By fixing exchange rates and by coordinating their economic policies, the actual Members of the Union can increase real integration, make inflation converge, attune business cycles and make the relationship between domestic inflation and real demand pressure similar across Member states. Over time this creates the most favourable conditions for optimality. These forces were present and certainly had a role in favouring the birth of EMU. Indeed, when one considers EMU, one immediately realizes that different considerations from those focused on in the canonical currency unions were playing a role in the creation of EMU. EMU is a monetary union, i.e. something more than a currency union, whose birth can be explained, on one side, by the difficulties of making a currency union work in an environment of free capital mobility and deeper integration and, on the other, by the benefits offered by the control of a stronger common currency.

A different explanation of EMU is that fiscal profligacy during the 1980s and 1990s was increasing public debt in many European countries, thus implying monetary accommodation, high inflation and exchange rate instability. In some countries, the trend was not sustainable and the risk of default loomed in the background. Furthermore, Europe - unlike the US -- was not in a position to borrow abroad. The creation of a totally independent, and thus non-accountable, central bank was deemed to be able to eliminate the possibility of governments monetizing public debt.

A further interpretation is possible if we consider exchange rate policies. After the demise of the Bretton Woods system, all countries were forced to come to terms with their exchange rate policy. Some did this quite soon, others later on; and two strands of behaviour can be detected among the variety of experiences. On the one hand, all countries faced increasing financial interdependence and countries in all continents started to face increasing risks of exchange rate shocks, particularly where the financial sector and the domestic economy were not robust. To achieve monetary independence in an environment of increasing capital mobility, some countries let their currency float while others -- a notable case being European countries that were integrating -- realized that, in order to fully exploit the economies of scale made possible by economic integration, some form of fixity in exchange rates and macroeconomic convergence were necessary. Europe made two experiments. The first, during the early 1970s, was a system of bilateral pegging bands among the European currencies and the US dollar. This so-called "Snake in the Tunnel” was not a successful experiment. The EMS-ERM European Monetary 
System - Exchange rate Mechanism) and the ECU (European Currency Unit) was the second and less unsuccessful one. Unlike the first, it showed that by fixing European bilateral exchange rates, some convergence in money aggregates and inflation rates was possible. In itself, the EMS-ERM was not able to bring about really stable exchange rates, but it did allow Europe to understand that in order to achieve exchange rate stability some other form of stability was necessary, notably that in the money market and other financial markets. To make EMS-ERM -- i.e. a currency union -- functional, Europe realized that it was necessary to turn the independent national central banks managing a system of target bands into a central bank managing a common currency. This offered a solution to the famous trilemma according to which it is impossible to retain full control of monetary policy, and keep the bilateral exchange rates stable when capital is increasingly mobile. Economic and financial integration seems to require something different or something more from stability in exchange rates as the EMS-ERM experiment made policy-makers understand: that integration in the money and financial markets must be guaranteed. Experience shows that intermediate exchange rate regimes, i.e. regimes aiming at fixing exchange rates are inherently unstable thus restricting the choice to only two options: perfect flexibility or perfect stability. The EU chose perfect internal stability, in order to enhance internal integration, and perfect external flexibility in order to retain freedom in monetary policy so as to fight inflation most effectively. The rationale for this being that economic adjustment can be obtained more efficiently by variables such as factor mobility, trade and price flexibility rather than exchange rates and demand policies. Exchange rate flexibility, indeed, could be more of a problem than a solution and increased trade integration makes demand policies less and less effective.

The exchange rate and integration option is also being pursued by the current experience o Asia and other Pacific countries Wyplosz (2001) and Eichengreen (2004). There is evidence that in order to keep their exports competitive internationally Asian and Pacific countries are trying to reduce volatility in exchange rates both in the region and towards major trading partners and notably the US dollar. This is demonstrated by the practice of managing the domestic currency's exchange rates against a basket of major trade partners' currencies, as China started to do in 2005. Although there is no clear political will of pushing an economic integration economic policy seriously ahead by creating suitable institutions and freeing domestic monetary policy from the national government, those countries are integrating their economies by adopting trade agreements, removing trade barriers, and managing exchange rates. Trade integration is already high and increasing and some countries have also established bilateral swap agreements in order to face possible crises in managed exchange rates.

\section{Convergence to EMU}

Convergence in the Euro area is predominantly that included in the criteria that were established with the Maastricht Treaty and thereafter used to show the progress towards the adoption of the common currency by the Members of the EU-15 until 1998. It still applies to the countries that are not full participants in EMU and in particular to the countries that became members in 2004 and 2007. As of now, $15 \mathrm{EU}$ Member States have adopted the euro while the other 12 are at present not full participants. Cyprus Malta are the last countries that have been found to meet all the criteria (ECB, 2007 and 2008a) and thus adopted the euro on 1 January 2008. As the UK and Denmark have opted out of EMU, there are 10 
States (Sweden included) that have been or will be asked to converge and apply for examination in the future. Of these, Slovakia seems to be closest to entry.

The convergence criteria adopted by the EU focus on price developments, fiscal developments, exchange rate developments and one long-term interest-rate development. It is striking that they all focus on nominal convergence as opposed to real convergence, i.e. per capita GDP. They also neglect real integration, i.e. the aspects that have always thought to be necessary to the existence of currency unions. There has been an intense debate over the entire project and the admission criteria and over whether both nominal and real convergence are needed. De Grauwe (1994), for instance, remarked that the Maastricht criteria were an obstacle to monetary union; while a more optimistic view posits that nominal convergence makes real convergence easier. The debate continues now over the sustainability of the monetary union. The widening differences in competitiveness and the ensuing trade imbalances -- that were initially deemed unimportant as the integration of financial markets would allow them to be financed -- have now gained centre stage. More in general, it can be said that divergence in terms of economic growth and per capita income could weaken political consensus for euro policy-makers (The Economist, 2008). The criteria for evaluating the position of countries wanting to join the euro has remained basically the same as that used before the launch of the single currency.

- As regards price developments, the target is defined in terms of the average rate of inflation instead of the price level. The inflation rate is measured in terms of the HICP (Harmonized Index of Consumer Prices) in the admission country and must not exceed by more than 1.5 per cent the average rate of inflation in the three best Member States ${ }^{2}$.

- Fiscal developments are in terms of budget balance and public debt. The Stability and Growth Pact is basically a tool for keeping budget balances on track and making the fiscal position sustainable. There is a 3 per cent cap on the budget deficit, but the deficit must also have a countercyclical profile. Its trend must be decreasing in those countries where the debt ratio is not below 60 per cent. This regards the convergence of single economies. There is, however, the issue of macroeconomic governance and policy of the Euro area per se. It is obvious that the enlargement of the EU will make the limits of European economic governance increasingly evident.

- The exchange rate needs to be stable, i.e. observe the normal fluctuation margins of the ERM-II ${ }^{3}$ with no devaluation or change in the central parity for at least two years.

- Interest-rate developments refer to yield spreads in long-term securities. The yield has to be within the 2 per cent margin of the three bestperforming Members. Large spreads would indicate that the market believes that securities of the same maturity in the different member countries are not of the same quality, as expectations on the official rate and short term yields are necessarily the same in a monetary union or in a currency union such as ERM-II. A narrow or a non-existent spread signals that the securities of two different governments are basically equivalent. A narrowing spread signals that the market believes that a country is going to

\footnotetext{
${ }^{2}$ In the last Convergence Report (ECB, 2008), this implies that the average of the three best Members States (1.7 per cent) augmented by a 1.5 per cent posits a limit of 3.2 per cent on HICP inflation in the admission countries.
}

${ }^{3}$ ERM-II is the ERM since the introduction of the euro (1 January 1999). 
be accepted into the euro zone. In this case also, the security market would forgive any difference in default risk if the different issues were not of the same quality as if admission per se brings with it an implicit bail-out option.

\section{Convergence within EMU}

Within EMU, nominal convergence basically boils down inflation, budget deficit and public debt. Indeed, exchange rates no longer exist and long-term interest rates have shown strong convergence across countries, although some widening started to emerge in 2008.

- Under the current mandate, the ECB seeks to promote price stability, which means that the HICP inflation rate is expected to be close to but below 2 per cent in the medium term. The limit is deliberately unambiguous and was decided autonomously by the ECB. The Bank's Council also has full operational independence in setting interest rates to ensure price stability. The limit of 2 per cent for the Euro area has always been considered too low for two reasons. In the first place, it compares with the target interval of 2 per cent \pm 1 per cent which many other central banks adopt ${ }^{4}$. De facto, the ECB tolerates less inflation than other respectable central banks. This might be explained by bearing in mind the opportunity cost of inflation. Even if the ECB's mandate contemplates price stability only, growth matters. By choosing a lower inflation limit, the ECB shows it believes that the opportunity cost is a lower growth rate than otherwise ${ }^{5}$. In the second place, critics have claimed that the euro zone is rather heterogeneous ${ }^{6}$ thus requiring either more dispersion around the limit of 2 per cent, or a higher limit. Recognizing that inflation expectations are among the main causes of inflation, the ECB believes that by anchoring expectations it is able to deliver the best outcome. As to be effective in anchoring expectations, a bank must be credible, the ECB adopted a strategy combining independence from the political power and commitment to a formal, explicit and rigid target. Until recently, its strategy was different from that of the Federal Reserve (Fed) since instead promoting both price stability and maximum sustainable employment as does the Fed, the ECB pursues price stability only and announces its inflation target because it wants to be accountable. It is, therefore, particularly interesting to see whether the ECB's strategy has been able to deliver price stability ${ }^{7}$. The ECB shows itself to be acutely interested in understanding the inflation process by investigating not only past performance, but also by refining its forecasts on future inflation by using a number of monetary indicators, cost indicators, all sorts of models and by direct measures of inflation forecasts (ECB, 2008) ${ }^{8}$.

- Besides the 2 per cent inflation limit, the Euro area has other "magic numbers" for assessing monetary policy and fiscal developments in the

\footnotetext{
${ }^{4}$ Indeed, the UK, Canada, Sweden, Australia and Israel have 2 per cent \pm 1 per cent. Although Switzerland adopts the same limit as the ECB, Norway has 2.5 per cent. The Fed (Federal Reserve) and the BoJ (Bank of Japan) do not have a fixed target.

${ }^{5}$ On this point see further below.

${ }^{6}$ On this point see further below.

${ }^{7}$ Even if the ECB has only one target, sustaining growth is no less important.

${ }^{8}$ Ibid. p. 36-37.
} 
Member States. The 2 per cent HICP inflation target resembles the experience of West Germany before the euro. By assuming, quite optimistically, that the average long-run real growth rate in the Euro area is 3 per cent and that velocity of money circulation increases at 0.5 per cent, the average increase in the money stock is readily computed as 4,5 per cent, which is the money target of the ECB. By assuming that the nominal growth rate in the Euro area is 5 per cent, a public debt to GDP ratio constant at 60 per cent implies a budget deficit to GDP ratio of 3 per cent, i.e. $0.05=0.03 / 0.6$. It can be seen that neither inflation, budget deficit, public debt not real growth were really in line with the forecasts and targets implied by the "magic numbers" just mentioned.

- As for inflation, Table 1 shows the average inflation rate in the Euro area from 1997 -- i.e. the year that was the reference for the initial convergence assessment that marked the end of stage II of $\mathrm{EMU}^{9}$-- to 2006, i.e. the eighth year of stage III. The first point to be noted is the difficulty that the ECB faced in bringing the area-wide inflation rate below the 2 per cent limit even during a period in which inflation was subdued globally. The second point is the presence of stable inflation differentials. Table 1 shows that three of the economies with a higher than 2 per cent rate of inflation are slow-growers (Italy, Portugal and The Netherlands) while the rest are fast-growers (Spain, Greece, Luxembourg, Ireland and Slovenia). The difference clearly reflects those experienced during the EMS-ERM as if the common monetary policy were not entirely effective. The ECB's mandate is about area-wide stability. It cannot limit changes in relative prices either across sectors or across countries, thus the persistence of the inflation differentials that are shown in Table 1 cannot be judged a failing ${ }^{10}$ in the common monetary policy. It cannot do much about it, but -nevertheless -- it cannot ignore it.

- Indeed, the ECB (ECB, 2005 and 2008b) is well aware that inflation differentials reflect both healthy adjustments in relative prices and the vices of the single economies, but its conclusion seems to be that existing disparities in the inflation rate are not destabilizing the real economy. As is well known, under a common monetary policy, inflation disparities feed back on the real economies in at least three different ways. Real interest rates are comparatively higher in the countries where inflation is lower, which is destabilizing if a lower inflation rate reflects a weak demand. Real wages are higher and income distribution is shifted in favour of workers. In the same countries and by the same token, external competitiveness is enhanced when inflation falls. The net results are uncertain and probably not the same everywhere and require further analysis. According to the ECB (2005), real interest rates based on expected inflation as measured by inflation forecasts offered by Consensus Economics are less dispersed than is the case of real interest rates based on actual inflation. This means that, to a certain extent, money illusion is present in the euro zone if the expected real interest rate is lower than the actual one or, in other words, that anchoring of inflation expectations is not perfect ${ }^{11}$. Secondly, the ECB correctly points out that the effects of inflation differentials on real interest

\footnotetext{
${ }^{9}$ Stage II ended in 1998.

${ }^{10}$ It is in any case a confirmation that the upper limit of 2 per cent is too ambitious.

${ }^{11}$ If anchoring of expectations were perfect, actual inflation would not deviate systematically and too much from what the central bank has announced.
} 
rates are opposite to the effects on real exchange rates. Their effects on real demand are thus partially compensated. The ECB, however, does not take into account the effects on real wages, which are negative when inflation is higher than the average.

Table 1 - HICP Inflation in the EMU-15

\begin{tabular}{|c|cccccccccc|c|}
\hline & 1997 & 1998 & 1999 & 2000 & 2001 & 2002 & 2003 & 2004 & 2005 & 2006 & \\
\hline & \multicolumn{7}{|c|}{ Deviations from the Euro area average } & & & average \\
De & $-0,20$ & $-0,60$ & $-0,50$ & $-0,70$ & $-0,50$ & $-0,90$ & $-1,10$ & $-0,30$ & $-0,30$ & $-0,40$ & 1,39 \\
It & 0,20 & 0,80 & 0,60 & 0,50 & $-0,10$ & 0,30 & 0,70 & 0,20 & 0,00 & 0,00 & 2,26 \\
Be & $-0,20$ & $-0,30$ & 0,00 & 0,60 & 0,00 & $-0,70$ & $-0,60$ & $-0,20$ & 0,30 & 0,10 & 1,84 \\
Fr & $-0,40$ & $-0,50$ & $-0,50$ & $-0,30$ & $-0,60$ & $-0,40$ & 0,10 & 0,20 & $-0,30$ & $-0,30$ & 1,64 \\
Ne & 0,20 & 0,60 & 0,90 & 0,20 & 2,70 & 1,60 & 0,10 & $-0,70$ & $-0,70$ & $-0,50$ & 2,38 \\
Sp & 0,20 & 0,60 & 1,10 & 1,40 & 0,40 & 1,30 & 1,00 & 1,00 & 1,20 & 1,40 & 2,90 \\
P & 0,20 & 1,00 & 1,10 & 0,70 & 2,00 & 1,40 & 1,20 & 0,40 & $-0,10$ & 0,80 & 2,81 \\
Ir & $-0,40$ & 0,90 & 1,40 & 3,20 & 1,60 & 2,40 & 1,90 & 0,20 & 0,00 & 0,50 & 3,11 \\
& & & & & & & & & & & \\
Au & $-0,50$ & $-0,40$ & $-0,60$ & $-0,10$ & $-0,10$ & $-0,60$ & $-0,80$ & $-0,10$ & $-0,10$ & $-0,50$ & 1,56 \\
Fn & $-0,50$ & 0,10 & 0,20 & 0,80 & 0,30 & $-0,30$ & $-0,80$ & $-2,00$ & $-1,40$ & $-0,90$ & 1,49 \\
Lu & $-0,30$ & $-0,20$ & $-0,10$ & 1,70 & 0,00 & $-0,20$ & 0,40 & 1,10 & 1,60 & 0,80 & 2,42 \\
Gr & 3,70 & 3,30 & 1,00 & 0,80 & 1,30 & 1,60 & 1,30 & 0,90 & 1,30 & 1,10 & 3,57 \\
Sl & 6,60 & 6,70 & 5,00 & 6,80 & 6,20 & 5,20 & 3,60 & 1,60 & 0,30 & 0,30 & 6,17 \\
Cy & 1,60 & 1,10 & 0,00 & 2,80 & $-0,40$ & 0,50 & 1,90 & $-0,20$ & $-0,20$ & 0,00 & 2,65 \\
Ma & 2,20 & 2,50 & 1,20 & 0,90 & 0,10 & 0,30 & $-0,20$ & 0,60 & 0,30 & 0,40 & 2,77 \\
\hline euro-13 & $\mathbf{1 , 7}$ & $\mathbf{1 , 2}$ & $\mathbf{1 , 1}$ & $\mathbf{2 , 1}$ & $\mathbf{2 , 4}$ & $\mathbf{2 , 3}$ & $\mathbf{2 , 1}$ & $\mathbf{2 , 1}$ & $\mathbf{2 , 2}$ & $\mathbf{2 , 2}$ & $\mathbf{1 , 9 4}$ \\
\hline \hline
\end{tabular}

Source of Data: Eurostat

- Persistence in the inflation dynamics is usually defined as the tendency of inflation to converge slowly towards its long-run value following a shock that has led the inflation away from it (Angeloni and Ehrmann, 2004). It reflects basically two factors. The first is the measure by which inflation expectations reflect past inflation rather than future inflation. The second is the slope of the Phillips equation, i.e. the equation that relates the inflation rate to real demand pressure ${ }^{12}$. The fact that in the Euro area some countries are always above the average and the ECB target while others are steadily below both proves that persistence is high, i.e. that past inflation is still having an effect. There is, furthermore, ample empirical evidence of a flattening in the Phillips curves. This is unfortunate as a flatter Phillips curve implies a higher sacrifice ratio, i.e. the number of years that unemployment has to be higher than the natural rate to reduce the inflation rate by 1 per cent.

- There is consensus about the idea that the control of average and national inflation rates is not sufficient to ensure macroeconomic convergence inside EMU. Since the EU has a limited budget and EMU has no budget policy at all, the European case differs quite markedly from the case of federal states such as the US, Canada, and even Germany. The EU budget is not suitable for stabilizing real demand in its economy nor in that of the Euro area as a whole. It is focused on cohesion, but it cannot be asked to

\footnotetext{
${ }^{12}$ The ECB is trying to investigate the various aspects surrounding the Phillips curve (Kuester et al, 2007; Musso, et al., 2007) inflation dynamics and price-setting in the Euro area (Altissimo, et al., 2006).
} 
pursue stabilization of aggregate demand. A national government's budget should act as an automatic stabilizer both at national level and at the areawide level, but the poor coordination between national governments offers no support. As the common monetary policy is targeted at inflation, the lack of a common fiscal policy limits the stabilization capability in the Euro area as a whole.

- Convergence in the budget of each country is targeted at allowing automatic stabilizers to help smooth the path of the national economy without any reference to what the other countries do. This allows national governments to vary the fiscal balance in line with the cyclical position of the economy. The provisions of the Stability and Growth Pact put a 3 per cent cap on the budget balance. They also require that the budget balance net of the cyclical component should bring about the reduction of the public/GDP ratio to the target level, which is 60 per cent in the medium term. After the revision of the pact agreed in 2005, budgetary objectives are now calibrated with the debt ratio and the potential growth rate in each country, which means that in cyclically adjusted terms and net of temporary measures the target ranges between a 1 per cent deficit and a small surplus. After the creation of EMU, the adoption of a common monetary policy and the Growth and Stability Pact, long-term interest rates continued to show narrow spreads. While budget deficit remained broadly in line with the imperative of not exceeding the 3 per cent limit, public debt in high-debt countries did not show any strong tendency to decline below the 60 per cent target.

\section{Nominal and real convergence}

The case of Slovenia (Member since 2007) is different from that of Cyprus and Malta h became members in 2008 (see Table 1), and interesting. In 1997, Slovenia had a much higher inflation rate than the average of the Euro area but it showed it was able to converge to the mean. This was very positive because it was an example of both low persistence and successful admission. It is also indicative of what was and is the typical pattern of other transition economies in the EU. The transition process obviously requires a structural change in the economy. During such complex a transformation labour productivity and trade openness increase rapidly and this yields a temporary acceleration in the rate of real growth. In transition economies, real convergence and other big changes take place and this seems to imply a higher inflation rate. Real convergence, therefore, is said to require nominal divergence. The channels through which real convergence and the implied real adjustment in the level of prices feed on the inflation rate were investigated during the 1960s. There are two channels. The first and most well known is the Balassa-Samuelson effect which focuses on labour productivity in the different sectors of the economy. During transition, the gaps in productivities in the different sectors usually increase. As wages tend to be equalized across sectors, the combination of gaps in productivities and the equalization of wages makes inflation surge. This effect can be reinforced if the share of demand which is addressed to the non-tradable sectors increases over time along with the increase in per capita income and urbanization (this is the Linden effect). The latter focuses on the changing composition of the consumption basket which is enhanced by the rapid increase in per capita income and by changes in the composition of labour force and by urbanization. The two effects refer to the first channel. The second 
channel is focused on the degree of openness, which also increases during transition and integration. The increase in the degree of openness brings about changes in the structure of markets and in the degree of competition therein. If competition increases, the level of prices is reduced. But this is only one possibility. Indeed, other changes are present (such as catching-up) which might really fuel price increases. The sign of the net result is uncertain, but recent studies (See: Sánchez, 2006; Lein-Rupprecht et al., 2007) was able to show that in the new EU member states it was mainly negative and thus opposite to the BalassaSamuelson effect.

\section{Inflation and growth}

A well known empirical result (Barro, 1996) offers statistical evidence on the in the long-term relation between inflation and real growth. There are at least three different mechanisms at work behind what we see in the statistical relation going from real demand to inflation. As they offer different predictions about the effect that real growth exerts on inflation in the short run, the situation can be defined uncertain.

We have already referred to the Balassa-Samuelson theory. This theory consists in the proposition that inflation is proportional to the gap in labour productivity of different sectors, and it posits that if wages tend to be equalized across sectors, domestic inflation is proportionally higher. To some extent, this type of inflation differential is benign as it signals a technological catching-up in production.

The second theory is the so-called New Keynesian theory. It blends demand and supply considerations as it makes the inflation rate and the output gap mutually dependent. It also distinctly assumes that agents, the central bank included, are forward looking. The theory basically consists of a Phillips curve in which the current inflation rate is dependent on past inflation and expected inflation ${ }^{13}$, output gap and shocks. The output gap depends on the past and expected output gaps and the real interest rate. The latter is the control variable, and depends on the expected level of inflation and the output gap. Quite interestingly, the model has recently been used to make an assessment of inflation persistence in the Euro area on the basis of structural models ${ }^{14}$ (Kuester et al., 2007; Altissimo et al., 2006; Galì Rabanal, 2005; Angeloni - Ehrmann, 2004). The New Keynesian Phillips curve is still key in structural models, and particularly in the investigations that regard inflation persistence. Indeed, persistence increases if the Phillips curve ${ }^{15}$ flattens. Persistence also rises if agents do not have perfect information about the nature of shocks and the nature of the systems as, in this case, they put more weight on past inflation than on expected future inflation ${ }^{16}$. A space for the central banks opens up

\footnotetext{
${ }^{13}$ More precisely, past expectations of current inflation or, depending on the model, current expectations of future inflation.

14 Other investigations are performed with reduced-form models.

${ }^{15}$ Actually both traditional and New Keynesian Phillips curves are linear: Musso e al., 2007 and Altissimo et al., 2006.

${ }^{16}$ In the New Keynesian Phillips curve: $\pi_{t}=\gamma \pi_{t-1}+(1-\gamma) E_{t} \pi_{t+1}+\kappa y_{t}+\varepsilon_{t}$ persistence is seen to be high when the curve is flat ( $\kappa$ is low). In this case, adverse shocks have limited effects on the inflation rate if the gap is large $\left(y_{t}=-\varepsilon_{t} / \kappa\right)$. Persistence is also high when anchoring is weak, $\gamma$ is high and $\pi_{t}$ converges slowly to $\pi_{t+1}$.
} 
accordingly, since by anchoring expectations, the central bank facilitates agents' learning. This should reduce persistence. The differences in persistence that still exist across the Euro area may, indeed, be attributed to differences not only in the steepness of the curve, but also in the degree of rationality. In all cases, nonetheless, the relation between the inflation rate and the output gap is positive, although unstable according to the state of expectations about inflation. This also is the reason why the relation between the inflation rate and the output gap implied in any such New Keynesian model can be translated into a positively sloped relation between the inflation rate and the growth rate (Figure 1).

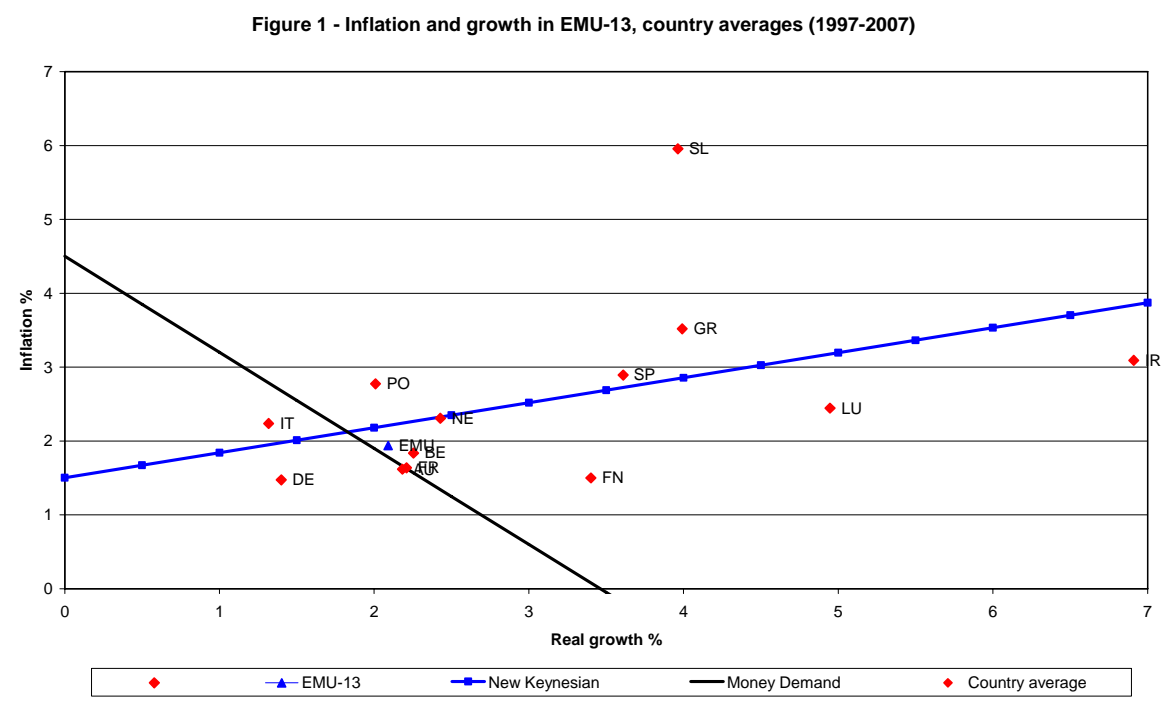

Source of Data: Eurostat,

A further way of looking at inflation and growth is based on the aggregate money demand equation which was estimated for the Euro area (Bruggeman et al., 2003 and Brand - Cassola, 2004). According to this theory, changes in the level of real output drive changes in the level of prices, given the amount of available liquidity and its velocity of circulation. In this case, the relation between the rate of real growth and the rate of inflation is inverse, which means that there is a possibility that a single monetary policy combined with permanent disparities in the rate of growth could be a source of inflation differentials per se, particularly if the euro money market fails to integrate perfectly. This theory offers a way of interpreting the observed differences in inflation across the Euro area which is different from that purported by the New Keynesian theory, but which is compatible with the empirical evidence about the long-run relation between inflation and growth investigated by Barro (1996)

Conventional money demand models assume that real GDP, interest rates and the price level are the determinants of the money that agents want in their portfolio and the recent estimates of the euro-wide money demand equation are no exception. Bruggeman et al., 2003 and Brand - Cassola, 2004, and ECB, 2004, for instance, estimate that a stable long-run demand equation for the whole Euro area , such as: $m_{t}=k+\alpha y_{t}-\beta i_{t} \quad$ exists; where: $m_{t}$ and $y_{t}$ are logarithms of the real stock of broad money and real GDP, respectively. $k$ is a constant, and $i_{t}$ is the spread between the market interest rate and the rate of return of the money itself, i.e. the opportunity cost of holding liquidity. In the different estimates, it turns out 
that the elasticity of GDP is always close to 1.3 , i.e.: $\alpha=1.3$. The estimate of the other parameter is significant, but changes according to the market interest rate used to define the spread. As a matter of fact, it is $-1.8 \leq \beta \leq-0.8$, and in what follows we will assume that: $\beta=1.3$. The ECB apparently manages to offer the euro system the right quantity of liquidity in the whole Euro area and manages to keep the short term interest rate at the right level. In doing this, it uses, among other things, excess liquidity measures derived from an equation of the type described above, on an aggregate basis. When there are permanent growth disparities inside and the money market is not perfectly integrated, the aggregate excess liquidity measure cannot signal differences stemming from those markets, but merely an average difference, and the common monetary policy may lead to inflation disparities across space. This can easily be seen by differentiating the demand equation with respect to time and using the resulting equation to translate the relevant real growth rate into an inflation rate. Let $g_{i}$ and $p_{i}$ indicate, as usual, the real growth and the inflation rates in country $i$. As the long-term rate of growth of the money stock is $n \&=0.045$ (Brand and Cassola, 2004), the equation in terms of percentage rates of changes corresponding to the one defined above is: $p_{i}=0.045-1.3 g_{i}$, as it is sensible to assume the spread as a constant, at least in the long run.

Thus, if we use the demand equation together with a growth rate, we might infer the implied inflation rate. As the ECB assumes that the euro zone has its own single demand equation and the single countries do not have one any longer, it is possible to assume that there is only one common inverse relation between the two variables in Figure 1. Figure 1 shows, therefore, the long-run money demand locus which, according to the ECB, holds in the euro zone. It predicts that when the money stock grows steadily at 4.5 per cent a year, the average inflation rate in the euro zone is a mere 1.9 per cent, if the real growth rate is also constant at 2 per cent. As is obvious, an increase in money growth will yield higher inflation, all things being equal. If that relationship between growth and inflation holds not only for the euro zone as a whole, but also for the single countries, one could say that slow-growing countries will experience inflation rates higher than the average while fast-growing ones would experience inflation rates lower than the average, in the long run. But will this happen? According to this theory, the answer will depend on the functioning of the money market. In the wholesale money market, the ECB system supplies liquidity to the banks and to the inter-bank market in the euro zone; while in the national retail markets, households and non-bank institutions apply to local banks. The pattern of inflation rates across the euro zone depends on how this dual market is able to channel liquidity and, thus, on its degree of integration. The target of a flat 2 per cent inflation rate both in slow growers and fast growers can be reached if liquidity can flow through the wholesale market from the retail markets in slow-growing countries, where it is abundant, to where it is scarce -- i.e. the retail markets in fast-growing countries -thus forcing countries to revert to the long-run demand curve. A uniform inflation rate could ideally be reached even if real growth were not the same across countries only if the wholesale market were able to channel liquidity as above. The assumption of a common monetary equation does not necessarily imply that the dual market is able to balance supply and demand of liquidity everywhere at the current common interest rate. The ECB is interested in making the internal money market as efficient as possible not only for the sake of making the transmission mechanism as rapid as possible, but also keeping it correctly tuned. The ECB itself 
aims at keeping the area-wide inflation just below 2 per cent; but it would be optimal if all member countries remained constantly at this same mark. In this case, the ECB target could be represented by the horizontal line drawn at 2 per cent. While the money demand locus represents the behaviour of the economy in the long-run, the horizontal line indicates the target for the euro zone and for its members. Money market inefficiencies and growth disparities, which are likely to increase in the enlarged euro zone, could bring about the observed disparities in inflation.

At first glance, although the long-run money demand locus in Figure 1 seems a good fit for the pattern of average rates in countries such as Austria, Germany, Belgium, France and Italy, it leaves some outliers (Ireland, Greece, Luxembourg, Spain and Slovenia); and from this point of view it offers a data fit looser than that obtained with the New Keynesian supply curve (Figure 1).

\section{Summary and Conclusions}

In this paper we have tried to summarise the criteria adopted to assess macro economic convergence in the Euro area . By considering convergence to the euro and within the euro, one immediately realizes that the credentials to be a member of EMU are different to those considered in the literature regarding currency unions. The criteria adopted to assess convergence to the euro practically coincide with those regarding convergence within it. This is remarkable since convergence to EMU is merely a selection procedure; while convergence within EMU is considered something necessary for good policy-making if not for making the union sustainable in the long run. Those criteria are basically nominal and are focused on fiscal and monetary developments.

Fiscal criteria are focused on budget deficits and debt-to-GDP ratios. Governments are asked to focus on the cyclical and non-cyclical components of the budget deficit. If they reduce the latter, then they can increase the former, thus increasing efficacy in their national fiscal policy. Furthermore, when governments reduce their debt ratios, they benefit from lower interest rates, which lowers their debt burden. This is held to be a virtuous mechanism provided that the reduction to zero of the non-cyclical component of the budget deficit while being imposed on debt-ridden governments does not become a general rule.

Monetary criteria regard inflation and exchange rates, but -- as is obvious -- for member countries they are limited to the inflation rate. The central bank is asked to pursue overall price stability, but cross-country differentials in terms of inflation rates and growth rates are quite important in a monetary area if they are persistent. Indeed, inflation differentials bear upon real interest rates; while growth differentials hinge upon per capita income differences and thus on political sustainability. The European Central Bank (ECB, 2008) is obviously more concerned with the overall performance in terms of price stability, but it is well aware of the risks implied by excessive and permanent differences across countries. In the last section we look at combined inflation and growth differentials lo see how they compare with predictions from theory. It is a commonplace that inflation dampens growth in the long run. This assertion is reinforced in a monetary union. In such a case, high inflation is also held to imply a competitiveness gap which cannot be eliminated through exchange rate adjustments (ECB, 2008) and which feeds back on real growth through the trade deficit. 
We then reach the relation that goes in the opposite direction, i.e. to the final point of the paper. There are at least three available predictions and they have been briefly summarized in the last section. According to the pure monetary argument, slow growth countries tend to have higher inflation. Thus they risk becoming trapped in a positive feedback loop between growth and inflation (slow growth reinforces inflation and vice versa). The New Keynesian paradigm is more reassuring in that it sees a positive relationship between inflation and growth. High growth economies tend to have higher inflation and vice versa. From the competitiveness argument just mentioned, according to which inflation dampens growth, it follows that between inflation and growth there is a negative feedback loop.

\section{References}

Altissimo, F., M. Ehrmann, F. Smets (2006) Inflation Persistence and PriceSetting Behaviour in the Euro Area, ECB, Occasional Papers Series, $\mathrm{N}^{\circ} 46$, June.

Angeloni, I., M. Ehrmann (2004) Euro Area Inflation Differentials, ECB, Working Papers Series, $N^{\circ} 388$, September.

Barro, R. (1996) Inflation and Growth, Federal Reserve Bank of St. Louis Review, 78, 153-169.

Brand, C., N. Cassola (2004) A Money Demand System for Euro Area M3, Applied Economics, 36, 817-838.

Bruggeman, A., P. Donati, A. Warne (2003) Is the Demand for Euro Area M3 Stable?, ECB, Working Papers Series, ${ }^{\circ} 255$, September.

De Grauwe, P. (1994), Towards EMU without the EMS, Economic Policy, 149154.

ECB (2005) Monetary Policy and Inflation Differentials in a Heterogeneous Currency Area, ECB, Monthly Bulletin, May, 61-77.

ECB (2007) Convergence Report, May.

ECB (2008a) Convergence Report, May.

ECB (2008b) Monthly Bulletin, 1998-2008 10th Anniversary of the ECB

Eichengreen, B. (2004) Real and Pseudo Preconditions for an Asian Monetary Union, paper presented at the Asian Development Bank High-Level Conference on Asia's Economic Cooperation and Integration, Manila, July 1-2.

Galí, J., P. Rabanal (2005) Technology shocks and Aggregate Fluctuations: How well does the TBC Model Fit Postwar U.S. Data?, NBER Macroeconomic Annual 2004, 225-288.

Kuester, K., G.J. Müller, S. Stölting (2007) Is the New Keynesian Phillips Curve Flat? ECB, Working Papers Series, $n^{\circ}$ 809, September.

Lein-Rupprecht, S., M.A. León-Ledesma, C. Nerlich (2007) How is real Convergence Driving Nominal Convergence in he New EU Member States?, ECB, Working Papers Series, $n^{\circ}$ 827, November.

McKinnon, R. (1963), Optimal Currency Areas, American Economic Review, 53, 717-25

Mundell, R. (1961), A Theory of Optimum Currency Area, American Economic Review, 51, 657-65.

Musso, A., L. Stracca, D. van Dijk (2007) Instability and Nonlinearity in the Euro Area Phillips Curve, ECB, Working Papers Series, $n^{\circ}$ 811, September. 
Sánchez, M. (2006) Implications of Monetary Union for Catching-up Member States, ECB Working papers Series, $\mathrm{N}^{\circ} 630$, May.

The Economist (2008) The CB at ten, A Decade in the Sun, June 7th, 71-73.

Wyplosz, C. (2001) A Monetary Union in Asia? Some European Lessons, in D. Gruen and J. Simon (eds) Future Directions for Monetary Policies in East Asia, RBA, Annual Conference Volume. Reserve Bank of Australia. 